\title{
The impact of different types of innovation and governmental support in the performance of firms: the case of Central and Eastern Europe manufacturing SMEs
}

\author{
FÁBIO de OLIVEIRA PAULA ${ }^{1}$ \\ JORGE FERREIRA DA SILVA ${ }^{1}$
}

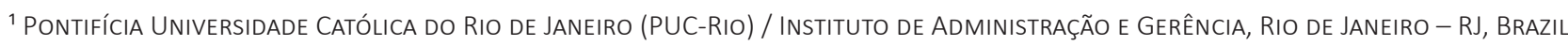

\begin{abstract}
This study examined companies from two different groups of countries in Central and Eastern Europe and their partnerships with the Government for the development of four types of innovation (product, process, organizational, and marketing). The research included ex-soviet republics (Eu members and non-members), and observed how each type of innovation affects the firms' financial performance. A sample of 1,143 manufacturing SMEs from the Business Environment and Enterprise Performance Survey (BEEPS) were tested using multiple regression and logit. Based on the absorptive capacity theory, the results show that manufacturing SMEs from EU-member countries have a higher absorptive capacity and take advantage of the EU's innovation promotion programs to innovate. On the other hand, the SMEs from non EU-member states perceive a quicker effect of the innovations in financial performance, considering that there is a technological gap between the two groups (non EU-members are less developed). Also, the introduction of different types of innovations simultaneously boosts the performance of firms from non EU-member countries in the short run.
\end{abstract}

Keywords: Innovation performance. Governmental support. Financial performance. Central and Eastern Europe (CEE). European ex-Soviet Republics.

O impacto dos diferentes tipos de inovação e do apoio governamental no desempenho das firmas: o caso das PMEs de manufatura da Europa Central e Oriental

\begin{abstract}
Resumo
Este estudo investigou a importância de parcerias com o Governo para o desenvolvimento dos quatro tipos de inovação (produto, processo, organizacional e marketing) por empresas de dois grupos diferentes de países da Europa Central e Oriental, incluindo as ex-repúblicas soviéticas europeias (países membros da União Europeia- MUE, e países não membros da União Europeia- NMUE); e como cada tipo de inovação afeta o desempenho financeiro das empresas. Para atingir esse objetivo, uma amostra de 1.143 PMEs de manufatura do Business Environment and Enterprise Performance Survey (BEEPS) foi testada, usando regressão múltipla e logit. Baseado na teoria da capacidade absortiva, descobriu-se que as PMEs de manufatura da UE têm uma capacidade absortiva mais alta e obtêm vantagem dos programas de promoção de inovação da UE para inovar. Por outro lado, empresas NMUE percebem um efeito mais rápido das inovações no desempenho financeiro, uma vez que existe uma lacuna tecnológica entre os dois grupos, sendo os NMUE menos desenvolvidos. Além disso, a introdução de diferentes tipos de inovações em simultâneo pode impulsionar o desempenho das empresas NMUE no curto prazo.
\end{abstract}

Palavras-chave: Desempenho de inovação. Apoio governamental. Desempenho financeiro. Europa Central e Oriental (ECO). Ex-repúblicas soviéticas europeias.

\section{El impacto de los diferentes tipos de innovación y el apoyo del gobierno en el desempeño de las empresas: el caso} de las PyME manufactureras de Europa Central y Oriental

\section{Resumen}

Este estudio investigó la importancia de las alianzas con el Gobierno para el desarrollo de los cuatro tipos de innovación (producto, proceso, organizacional y marketing) en empresas de dos grupos diferentes de países de Europa Central y Oriental (ECO), incluyendo las antiguas repúblicas soviéticas europeas (países miembros de la Unión Europea -UE, y países no miembros de la UE); y cómo cada tipo de innovación afecta el desempeño financiero de las empresas. Para alcanzar esta meta, se probó una muestra de 1.143 PyME manufactureras del Business Environment and Enterprise Performance Survey (BEEPS) utilizando regresión múltiple y logit. Con base en la teoría de la capacidad de absorción, se encontró que las PyME manufactureras de países de la UE tienen una mayor capacidad de absorción y se benefician de los programas de promoción de la innovación de la UE para innovar. Por otro lado, las empresas de los países no miembros de la UE perciben un efecto más rápido de las innovaciones en el desempeño financiero, ya que existe una brecha tecnológica entre los dos grupos, y los países no miembros de la UE son menos desarrollados. Además, la introducción de diferentes tipos de innovaciones simultáneamente puede mejorar el rendimiento de las empresas de países no miembros de la UE a corto plazo.

Palabras clave: Desempeño de innovación. Apoyo gubernamental. Desempeño financeiro. ECO. Antiguas repúblicas soviéticas europeas.

Article submitted on March 27, 2018 and accepted for publication on December 07, 2018

[Original version]

The present research was conducted with the support of FAPERJ, Carlos Chagas Filho Foundation for Research Support of the State of Rio de Janeiro, and CNPq, National Council for Scientific and Technological Development.

DOI: http://dx.doi.org/10.1590/1679-395174365x 


\section{INTRODUCTION}

More than 27 years after the fall of the Berlin wall, the economic transition of the Central and Eastern Europe (CEE) countries, which includes the European ex-soviet republics, were successful (ASLUND, 2014; ATELJEVIĆ and TRIVIĆ, 2016) as they became real market economies. However, significant differences can be found among these countries. The inequality between them can be perceived through an analysis of three widespread indicators: the gross domestic product per capita (GDP), the human development index (HDI) and the global innovation index (GII). According to the World Bank (2015), Slovenia is the best among these countries in GDP ( $33^{\text {rd }}$ in the world). On the other hand, Moldova is the worst ( $135^{\text {th }}$ position worldwide). Analyzing the HDI, Slovenia is also in the best position ( $26^{\text {th }}$ in the world), and Moldova is again in the worst, only in the $107^{\text {th }}$ position (UNITED NATIONS, 2015). If we consider the innovative capacity of the country (GII), Estonia is in the $24^{\text {th }}$ position compared to the rest of the world and Albania is the worst, in the $92^{\text {nd }}$ position.

Those differences show that the economic development and life quality in ex-socialist countries in Europe are at different stages, which may be caused by various factors. One of the factors is the entrance of some of those countries in the European Union. Countries that entered in the European Union (CEUs) had previously to comply with the EU's financial standards and rules (EUROPEAN COMMISSION, 2017a). After this, they had free access to the other EU members' market and its citizens had free movement throughout EU allowed. The difference between the ex-socialist countries that are in the EU and the ones that are not (CNEUs) are clear if we look again at the three indicators mentioned above. On the average, CEUs are positioned as $50^{\text {th }}$ in GDP, $40^{\text {th }}$ in $\mathrm{HDI}$ and $36^{\text {th }}$ in GII. On the other hand, CNEUs are $102^{\text {nd }}$ in GDP, $82^{\text {nd }}$ in HDI and $66^{\text {th }}$ in GII.

Participation in the EU may be in part cause and in part consequence of a more advanced stage of economic development. It seems clear, however, that the CNEUs will need to achieve a higher level of economic development before they have an opportunity to get in the EU, and, as Christensen and Raynor (2003) taught, one way that a country may obtain economic growth is by having the innovativeness of national firms improved. In a developing country, firms usually are not in the technological frontier and, besides the firm's own efforts (FAGERBERG, MOWERY and NELSON, 2006), need governmental support to develop the necessary technological capabilities to innovate (BELL and FIGUEIREDO, 2012; CHOUNG, HWANG and SONG, 2014; KIM, 1997; PAULA and SILVA, 2017). Potentiate the effectiveness of the governmental support and of the firms' efforts to develop innovations is especially important for small and medium-sized enterprises (SMEs), which exert a strong influence in the growth of developing economies (ZENG, XIE and TAM, 2010).

The innovation process occurs in different ways and has different contingencies depending on the innovation type. The Oslo Manual (OECD, 2005) classified innovation under the following types: i) product innovation; ii) process innovation; iii) marketing innovation; and iv) organizational innovation. It is essential to identify which types of innovation are more efficient to improve economic performance and which ones are more likely to be improved by governmental support in different contexts so that their governments can prioritize their investments and efforts. We also based on the absorptive capacity theory (COHEN and LEVINTHAL, 1990), which links the capacity of firms to innovate through partnerships with a capability developed by the firm to value, assimilate and apply external resources, to argue that firms can improve their innovation performance through partnerships with the government more effectively if they develop an appropriate level of absorptive capacity.

The primary goal of this study was to identify opportunities for the CNEUs to improve the capacity of their governments to support innovation on its firms to improve their innovation and economic performance. Although CNEUs may take lessons from the most innovative countries of the world, CEUs are more innovative compared to them and have more to teach as the history and culture of the countries of the two groups are more related. Therefore, this study intends to answer the following question: What are the similarities and differences among CEUs and CNEUs in the effect of the governmental support for innovation introduction by local firms and in its effect on their economic performance, that may have allowed CEUs to have a faster economic development? 


\section{LITERATURE REVIEW}

\section{Differences among CEE Countries: The Role of EU}

The independence of the ex-soviet republics and the end of communism in the CEE did not come harmlessly. Those countries presented a substantial fall in their GDPs in the early of 1990s and recovered only by the end of the decade (APANASOVICH, HERAS and PARRILLI, 2016). The transition from a planned economy to a market economy demanded high costs of economic, political and social institutions and of infrastructure restructuring (FEIGE, 1994). However, it allowed most of the countries to have a bigger share of the global economy nowadays and increased their GDP per capita, with countries that implemented the reforms faster, privatized the state-owned companies and deregulated more intensively having achieved better results (ASLUND, 2014).

One of the most important drivers of the economic development of a part of these countries was their accession to the EU, a process that began in 2004. The process of economic integration of the CEUs with the EU market promoted opportunities and challenges for these countries' firms that allowed the rise of their competitiveness (GHAZALIAN and FAKIH, 2017). Analyzing some indicators of the CEUs in comparison with the CNEUs (e.g., GDP, HDI and GII, which were addressed previously) clarifies that the first group of countries is in a more advanced stage compared with the second group.

Another important issue concerns the National Systems of Innovation (NSI) of the CEE countries, which changes according to the country (PATEL and PAVITT, 1994). Generally, they are weak and fragmented (RADOSEVIC, 2005), and lack efficient innovation policies. However, the EU has supra-national innovation policies that help speed up the development of the NSI of its countries. The Horizons 2020 program concentrates most of the policies developed by the European Commission to foment the development and broaden the use of innovative manufacturing technologies and business models (EUROPEAN COMMISSION, 2018). Although some studies argument that EU innovation policies are not appropriate for CEE countries (LENGYEL, SEBESTYÉN and LEYDESDORFF, 2013), firms from the CEUs have a clear advantage over the ones from the CNEUs regarding the availability of access to innovation programs. The average differences regarding the GII previously discussed reinforces this assertion.

\section{Innovation and Financial Performance}

The relationship between innovation and financial performance has been consistently found in several empirical studies (DU, LETEN and VANHAVERBEKE, 2014; YAMAKAWA, YANG and LIN, 2011). In today's uncertain environment, innovation is essential for firm's survival (TEECE, 2007). According to Ateljević and Trivić (2016), "innovations make firms to produce better quality products and services, with lower costs and faster" and those firms may "increase the possibility to build a better competitive position in the market, to increase its profitability and to strengthen its stability." According to Schoenmakers and Duysters (2010), radical innovations are the driving forces of technological, industrial and societal change. When a radical innovation occurs in the industry, the performance of incumbents tends to decrease, whereas new ventures pioneer the innovation introduction (HILL and ROTHAERMEL, 2003). Even if the introduction of a radical innovation that will change industry patterns does not happen, many authors recognize the importance of incremental innovation for performance. Tomlinson (2010) found a positive relationship between product and process innovation and factors that may indicate performance, such as firm size and sales growth. Some authors detected that open innovation activities performed by firms have a positive relationship with customer and financial performance (DU, LETEN and VANHAVERBEKE, 2014).

Teece (1986) explained that the relationship between a firm's innovation level and financial performance depends on three concepts: i) appropriation regime, which is the mechanisms a firm uses to guarantee that it will benefit from a fair part of the innovation rents; ii) dominant design paradigm, so that if the company can make the innovation an industry standard, it will strongly contribute to financial results; and iii) complementary assets, that is how much of the assets necessary to put innovation to market (marketing, distribution, manufacturing) the firm possesses. These influential factors may have enabled CEUs firms to be more effective in turning innovation performance into a higher financial performance than CNEUs firms. The appropriation regime, in some sort, depends on the NSI. The efforts countries need to make to comply with the regulations necessary to get into the EU may have allowed CEUs' appropriability regime to be stronger. Complementary assets may also 
be achieved at a higher level by firms of the CEUs, as free access to the EU market may have opened more opportunities for partnerships with other firms that have them. This free access to the EU market also may have improved opportunities for CEUs firms to export, which demanded them to be more productive and competitive (CASSIMAN and GOLOVKO, 2011).

Diverse types of innovation have different contingencies. This article used the classification of innovation proposed by the Oslo Manual (OECD, 2005), that classified innovation under four types: i) product innovation; ii) process innovation; iii) organizational innovation; and iv) marketing innovation.

Product innovation improve performance by allowing the firms to meet demand gaps (GALINDO and MÉNDEZ, 2014) with better quality or lower cost products (ATELJEVIĆ and TRIVIĆ, 2016). Process innovation also helps to reduce the products' costs by improving the productive process (MOUTINHO, AU-YONG-OLIVEIRA, COELHO et al., 2015) and increasing productivity (TERJESEN and PATEL, 2017).

Product and process innovations occur in different degrees at diverse phases of the product life-cycle (UTTERBACK and ABERNATHY, 1975). In the introduction and growth phases, radical followed by several incremental product innovations occur to develop the product and try to stablish a dominant design. As the product matures, the amount of product innovations declines, and process innovations are more frequent to improve efficiency and lower costs. Products in their initial stages are more related to the exploration of new technologies while mature products are more related to exploitation, and the equilibrium between exploration and exploitation is necessary for the long-term success of a firm (MARCH, 1991), as the second guarantees today's revenues while the first will generate future revenues. Therefore, an equilibrium in the investments on product and process innovation is necessary for a better financial performance in the long run.

Organizational innovation, in its turn, is context-specific and, for this reason, is one of the most sustainable sources of competitive advantage (HAMEL, 2009). It has a great impact on profit margin and competitiveness, especially on small SMEs, (LAFORET, 2013). Camisón and Villar-López (2014) found a direct positive relationship between organizational innovation and performance, which may rely on the fact that strategic renewal is achieved by this type of innovation and improves the resilience of firms against external turbulence (HAMEL and VÄLIKANGAS, 2003). They also found an indirect relationship based on its positive relationships with other types of innovation, mainly process innovation, as the introduction of new rare, valuable, inimitable and non-substitutable working practices introduced by organizational innovation may favor the development of technological capabilities (CAMISÓN and VILLAR-LÓPEZ, 2014).

Marketing innovation is also essential for improving the performance of firms. The capacity to adopt marketing innovations increases the competitiveness of a brand and of its resellers in the market (GUPTA, MALHOTRA, CZINKOTA et al., 2016), in a supplier-client partnership. According to the authors, a brand growth is dependent on identifying and conquering new markets by the resellers and applying innovative marketing practices. At the same time, the brand should support the resellers to succeed in this approach providing resources and innovative brand marketing strategies.

The four types of innovation mentioned above may create value by themselves. However, as innovation has a systemic character, in which not only the technological dimensions (product and process innovation) should be considered, but also marketing and organizational innovations (VEGA-JURADO, JULIAO-ESPARRAGOZA, PATERNINA-ARBOLEDA et al., 2015), firms that succeed in the introduction of the four types of innovation may perform better than firms more focused on one type of innovation. The government plays an important role on incentivizing systemic innovation in firms in general (and specially in SMEs) not only making financial resources available, but also developing innovative activities and encouraging collaboration.

All that was said previously reinforces that the effective investments in innovation by firms from less developed countries are important to help them catch-up to the level of competitiveness of firms from more developed economies (KIM, 1997, 1998). As those organizations lack basic knowledge and resources and are usually very lagged compared to their foreign competitors, starting innovating effectively would improve their productivity and financial performance much faster than it would in more competitive firms. The aforementioned theories also advocated that the broader the innovativeness of the firm, in terms of innovation types (product, process, organizational or marketing), the more effective would be the innovative efforts, as the different types of innovation have great synergy. Considering all this, firms from CNEUs, including 
manufacturing SMEs, would experience the effects of the innovations introduced faster in comparison with the CEUs, deriving our first hypothesis.

Hypothesis 1. The innovation performance has a stronger positive impact on financial performance in the short-term in manufacturing SMEs from the CNEUs than from the CEUs. This positive impact is more intense if the innovativeness of the firm is systemic, which means that it encompasses various types of innovation (product, process, organizational and marketing) concomitantly.

\section{The Role of the Government}

The government has an essential role as an inductor or a detractor of innovation, especially in developing economies (HONG, FENG, WU et al., 2016). According to the authors, there are several types of support governments may provide for firms' innovation i.e., tax preference, loans that stimulate innovation, subsidies on innovation activities, and government funding programs. Kim (1997) stated that the government influences the availability of domestic and international sources of technological learning as it defines national industrial, trade, monetary and educational policies. For Bell and Figueiredo (2012), economywide factors that are influenced by the government are important for influencing firm's investments in technological capabilities and R\&D, such as the degree of competition controlled by the level of protection versus openness of the trade policy and the level of subsidies. However, subsidies can be counterproductive if they are not followed by performance incentives, such as the obligation to compete in the international market through exports. According to Propris (2002), as product and process innovation performance of firms improves with the cooperation with partners, the government action is important to establish innovation policies that support alliances among firms to induce innovation.

In many cases in developing economies, only with the help of the government local firms can catch-up to the technological frontier and become world-leading innovators. Kim (1998) and Lee and Lim (2001) demonstrated that, in the case of some Korean firms, governmental incentives succeeded by creating artificial crises that imposed firms to innovate and compete effectively in the global market. All those governmental incentives came with performance requirements based on export goals. However, these types of policies should be temporary and encourage firms to be able to compete with global leaders by themselves in the future incentivizing technological accumulation that allows them to become actual innovators. As CEUs firms have open access to EU markets, they export more (see Table 1) and compete at a higher level.

The previously mentioned arguments support the proposition that the government can be an important partner for innovative firms. According to the absorptive capacity theory, a firm must have an appropriate level of absorptive capacity - AC (COHEN and LEVINTHAL, 1990), which is the ability of a firm "to recognize the value of new, external information, assimilate it, and apply it to commercial ends." (ibid., p. 128), to succeed in any type of innovation partnership, including the ones with the government. Governmental subsidies are usually finance-based. The ability to identify the governmental programs that fit the firms' innovation projects are strongly related to previous experience and current knowledge in innovation that the firm possesses, which are dimensions of AC (ZAHRA and GEORGE, 2002).

On the one hand, all aforementioned supports that the subsides from the government are important for the development of the NSI of developing economies and to encourage the innovativeness of firms. On the other hand, more developed countries have stronger and better orchestrated NSIs. CEUs, besides individually more developed than CNEUs, participate of the EU. Their firms benefit from its continental market and must compete with rivals from the most developed European countries, which demands some level of innovativeness. The set of firms in these countries, conjointly with universities, the government and other actors, help to develop stronger NSIs than the ones from the CNEUs. Besides, firms from the CEUs can take advantage from EU-level innovation policies, for instance the initiatives subordinated to the program Horizons 2020. All these lead us to our second hypothesis.

Hypothesis 2. The subsides from the government (or from the EU) have a stronger positive impact on the innovation performance of manufacturing SMEs from the CEUs than from the CNEUs. This relationship is moderated by the absorptive capacity of the firm. 


\section{METHOD}

\section{Data Source and Sample}

Data from the Business Environment and Enterprise Performance Survey - BEEPs, conducted by the World Bank and the European Bank for Reconstruction and Development (EUROPEAN BANK FOR RECONSTRUCTION AND DEVELOPMENT, 2016), was used to test the hypotheses. BEEPs was considered appropriate for this study as this survey investigated several phenomena related to innovation activities (for instance the introduction of product, process, organizational and marketing innovation and internal R\&D) and financial performance at the firm-level, besides having information about the firms' characteristics, based on the year of 2011 (exceptionally, most firms of Slovakia and Czech Republic filled their surveys based on 2012), which was the latest published when this study was conducted. As BEEPs privileges mostly emerging economies, it has data of firms from the CEE, which are our focus.

The total sample was 3,716 firms from the CEUs (Bulgaria, Croatia, Czech Republic, Estonia, Hungary, Latvia, Lithuania, Poland, Romania, Slovakia and Slovenia) and 2,152 firms from the CNEUs (Albania, Bosnia and Herzegovina, Kosovo, Macedonia, Montenegro and Serbia). From those, we choose to keep only manufacturing SMEs according to the European Commission criteria (EUROPE COMMISSION, 2017b) in both the last fiscal year (2011 or 2012) and three years before (2008 and 2009), which resulted in a final sample of 1,143 organizations, being 684 from the CEUs and 459 from the CNEUs.

\section{Variables' Description}

The dependent variables of the study are three firm-level financial performance variables that compare the firm's result in the last fiscal year with the average from all the firms of the sample from the same industry and are: i) total sales / avg. industry; ii) num. employees / avg. industry; iii) productivity / avg. industry - productivity is the ratio between total sales and num. employees.

The independent variables are categorical measures of the introduction of at least one innovation by type in the period, being 1 (one) if that specific type of innovation was introduced in the last three years, and 0 (zero) if not: i) product innovation, ii) process innovation, iii) organizational innovation; and iv) marketing innovation. We also measured the systemic degree of innovation as the sum of the four categorical variables representing the introduction of the innovation types, representing the variety of types of innovation introduced conjointly from 0 (zero) to 4 (four). Governmental support as also a categorical variable, being 1 (one) if the firm had received any subsidies from local, regional, national government, or EU sources over the past three years; and 0 (zero) if it did not. We also used proxies of the absorptive capacity of the firms, that we interacted with governmental support to test hypothesis 2 : i) internal $R \& D$ - categorical variable, being 1 (one) if the firm had internal R\&D over the last three years and 0 (zero) if it did not; ii) employee education - \% of employees that have a university degree; and iii) top management experience - the top management's number of years of experience working in the firm's sector.

Finally, we considered the following control variables: i) subsidiary - 1 (one) if the firm is a subsidiary of a larger firm and 0 (zero) if it is not; ii) firm's age - number of years between the beginning of operations and the last fiscal year considered; iii) export intensity - direct exports as a percentage of total annual sales; iv) total annual sales (year-3) - considering fiscal year minus 3; and v) number of employees (year -3) - considering the fiscal year minus three.

\section{Statistical Method}

To test the hypotheses, we used a Weighted Regression Analysis when the dependent variables are scalars (that is the case of the financial performance variables and of Systemic Degree of Innovation) and Weighted Logistic Regression when the dependent variables are dummies (as in Product, Process, Organizational and Marketing Innovation). As the number of firms of one country is unbalanced, we weighted the value of each case by the proportion of the number of firms of its country in the group to give all countries the same weight in the analysis (GRIFFITH, HUERGO, MAIRESSE et al., 2006). Common-method bias was checked by running an exploratory factor analysis with all the variables of the model. If the total variance explained in one common factor was higher than $50 \%$, common-method bias was considered an issue (PODSAKOFF, MACKENZIE, 
LEE et al., 2003). The first step of the analysis consisted on the estimation of the innovation variables using governmental support, the absorptive capacity variables (alone and interacting with governmental support) and the control variables as independent variables separately by group of CEUs and CNEUs (see equation I), which tested the hypothesis 2 .

[product innovation, process innovation, organizational innovation, marketing innovation, systemic degree of innovation $]=\beta a 0+\beta a 1 *$ governmental support $+\beta a 2 *$ internal $R \& D+\beta a 3 *$ employee education $+\beta a 4 *$ top management experience $+\beta a 5 *$ (governmental support $*$ internal $R \& D)+\beta a 6$ $*$ (governmental support * employee education) $+\beta a 7 *$ (governmental support * top management experience $)+\beta a 8 *$ subsidiary $+\beta a 9 *$ firm's age $+\beta a 10 *$ export intensity $+\beta a 11 *$ total annual sales $+\beta a 12 *$ number of employees $+\varepsilon$

In the second step, the regression analysis of the financial performance variables by country group were estimated separately in two different ways to test hypothesis 1 . The first used the innovation dummies as independent variables (see equation II) and the second used systemic degree of innovation as independent variable (see equation III), with both testing also all the control variables as independent variables.

[total sales / avg. industry, number of employees / avg. industry, productivity / avg. industry] $=\beta \mathrm{b} 0+$ $\beta b 1 *$ product innovation $+\beta b 2 *$ process innovation $+\beta b 3 *$ organizational innovation $+\beta b 4 *$ marketing innovation $+\beta \mathrm{b} 5 *$ subsidiary $+\beta \mathrm{b} 6 *$ firm's age $+\beta \mathrm{b} 7 *$ export intensity $+\beta \mathrm{b} 8 *$ total annual sales + $\beta \mathrm{b} 9 *$ number of employees $+\varepsilon$

[total sales / avg. industry, number of employees / avg. industry, productivity / avg. industry] = $\beta$ b0 $+\beta \mathrm{b} 1 *$ systemic degree of innovation $+\beta \mathrm{b} 2 *$ subsidiary $+\beta \mathrm{b} 3 *$ firm's age $+\beta \mathrm{b} 4 *$ export intensity + $\beta \mathrm{b} 5 *$ total annual sales $+\beta \mathrm{b} 6 *$ number of employees $+\mathcal{E}$

\section{RESULTS}

We start presenting the descriptive statistics of the variables for the full sample and separated for the CEUs and the CNEUs. Table 1 shows that the CEUs' manufacturing SMEs have total annual sales significantly higher than the ones from the CNEUs ( $€ 2.11 \mathrm{MM}$ versus $€ 1.36 \mathrm{MM}$ on average) and the annual sales of the firms in both groups have grown compared to three years before. CEUs' manufacturing SMEs are also bigger in terms of number of employees (36.00 versus 31.21), however, the difference is lower in magnitude compared to annual sales, justifying the higher productivity of the firms in EU countries $(€ 58,611$ employee/year versus $€ 43,576$ from the CNEUs'). CEUs' manufacturing SMEs also export more, $22.5 \%$ of the annual sales, compared to $12.2 \%$ in the second group. It was expected that the formers should export more by their open access to the EU market. The CEUs' manufacturing SMEs have governmental support in a proportion of more than twice, compared to the ones from the CNEUs (23.0\% of the firms in three years versus $11.0 \%$ ). The results are consistent with the fact that firms from CEUs have access to EU innovation policies.

When it comes to absorptive capacity, CEUs' manufacturing SMEs score higher than CNEUs' only in top management experience, with 20.42 years on average against 18.07 years for the second group. Investments in internal R\&D and employee education have no significant differences between both groups. When it comes to innovation, there is no statistically significant differences in any type or in the systemic degree of innovation. $41.0 \%$ of the firms in the total sample introduced product innovation in the three years' period, $32.0 \%$ introduced process innovation, $28.0 \%$ introduced organizational innovation and $27.0 \%$, marketing innovation. The systemic degree of innovation is 1.29 on average for the whole sample, indicating that between one and two types were introduced in the period on average, but closer to one. Analyzing the financial performance variables, the comparison with the industry average favors the CEUs' manufacturing SMEs in all proxies. This group had an average total sales 1.15 times the industry while the CNEUs' manufacturing SMEs had 0.78 times. The pattern repeats for number of employees (1.06 times the industry average versus 0.91 ) and for productivity (1.17 versus 0.75$)$. These indicators show that the CEUs' manufacturing firms beat the CNEUs' in the competition inside their industries consistently. 
Table 1

Characteristics of the sample

\begin{tabular}{|c|c|c|c|c|c|c|c|}
\hline Variável & $\begin{array}{l}\text { Full s } \\
\qquad(\mathrm{n}=\end{array}$ & $\begin{array}{l}\text { mple } \\
\text { 143) }\end{array}$ & & & & & F-test \\
\hline & Mean & S.D. & Mean & S.D. & Mean & S.D. & \\
\hline Subsidiary & $5.0 \%$ & $21.2 \%$ & $6.0 \%$ & $23.5 \%$ & $3.0 \%$ & $17.2 \%$ & $* *$ \\
\hline Firm's Age & 15.94 & 12.32 & 16.84 & 12.63 & 14.60 & 11.72 & $* * *$ \\
\hline Export Intensity & $18.3 \%$ & $31.7 \%$ & $22.5 \%$ & $34.3 \%$ & $12.2 \%$ & $26.0 \%$ & $* * *$ \\
\hline Total Annual Sales & $1.81 \mathrm{MM}$ & $4.41 \mathrm{MM}$ & $2.11 \mathrm{MM}$ & $5.09 \mathrm{MM}$ & $1.36 \mathrm{MM}$ & $3.09 \mathrm{MM}$ & $* * *$ \\
\hline Number of Employees & 34.08 & 44.81 & 36.00 & 47.09 & 31.21 & 41.06 & $*$ \\
\hline Total Annual Sales (yr-3) & $1.63 \mathrm{MM}$ & $4.36 \mathrm{MM}$ & $1.92 \mathrm{MM}$ & $5.07 \mathrm{MM}$ & $1.211 \mathrm{MM}$ & $2.94 \mathrm{MM}$ & $* * *$ \\
\hline Number of Employees (yr-3) & 33.64 & 43.93 & 35.64 & 45.74 & 30.67 & 40.95 & $*$ \\
\hline Top Management Experience & 19.48 & 9.89 & 20.42 & 10.15 & 18.07 & 9.33 & $* * *$ \\
\hline Internal R\&D & $18.0 \%$ & $38.7 \%$ & $19.0 \%$ & $39.1 \%$ & $17.0 \%$ & $38.0 \%$ & - \\
\hline Employee Education & $16.2 \%$ & $20.5 \%$ & $15.9 \%$ & $20.9 \%$ & $16.6 \%$ & $19.9 \%$ & - \\
\hline Governmental support & $18.0 \%$ & $38.7 \%$ & $23.0 \%$ & $42.1 \%$ & $12.0 \%$ & $32.0 \%$ & $* * *$ \\
\hline Product Innovation & $41.0 \%$ & $49.3 \%$ & $41.0 \%$ & $49.2 \%$ & $42.0 \%$ & $49.4 \%$ & - \\
\hline Process Innovation & $32.0 \%$ & $46.8 \%$ & $32.0 \%$ & $46.6 \%$ & $34.0 \%$ & $47.3 \%$ & - \\
\hline Organizational Innovation & $28.0 \%$ & $44.7 \%$ & $26.0 \%$ & $44.0 \%$ & $30.0 \%$ & $45.8 \%$ & - \\
\hline Marketing Innovation & $27.0 \%$ & $44.5 \%$ & $27.0 \%$ & $44.2 \%$ & $28.0 \%$ & $44.9 \%$ & - \\
\hline Any Innovation & $57.0 \%$ & $49.6 \%$ & $58.0 \%$ & $49.4 \%$ & $55.0 \%$ & $49.8 \%$ & - \\
\hline Systemic Degree of Innovation & 1.29 & 1.40 & 1.25 & 1.35 & 1.33 & 1.46 & - \\
\hline Total Sales / Avg. Industry & 1.00 & 2.17 & 1.15 & 2.41 & 0.78 & 1.73 & $* * *$ \\
\hline Num Employees / Avg. Industry & 1.00 & 1.29 & 1.06 & 1.36 & 0.91 & 1.18 & $*$ \\
\hline Productivity / Avg. Industry & 1.00 & 1.77 & 1.17 & 2.10 & 0.75 & 1.06 & $* * *$ \\
\hline
\end{tabular}

$* \mathrm{p}<0.1$;** $\mathrm{p}<0.05$; *** $\mathrm{p}<0.01$

Source: Elaborated by the authors.

Then, we conducted an exploratory factor analysis of all variables of the model to check a possible existence of commonmethod bias. The common factor presented a total variance explained of $21.37 \%$, which is much lower than $50 \%$. So, we considered that common-method bias is not a relevant issue. Table 2 and 3 show the results of the weighted regressions for all the three financial performance variables per group, with regressions in table 2 using the innovation dummies and the ones in table 3 using systemic degree of innovation. Table 4 presents the results of the weighted logits that calculated the innovation performance variables and table 5, the regression for systemic degree of innovation as independent variable.

According to table 2 and 3, the hypothesis 1 (which stated that innovation performance, including systemic innovation, has a stronger positive impact on financial performance for manufacturing SMEs of the CNEUs) was partially accepted. The effect of innovation on financial performance for the CEUs' manufacturing SMEs present different a pattern compared to the CNEUs. For the first group, there is no significant effect of the introduction of the separate types of innovation in any performance indicators. In the case of the second group, the effect of process innovation is positive and significant on total sales/avg industry $(0.06$ for $p<0.1)$ and the effect of product innovation is positive and significant on num employees/avg industry $(0.06$ for $p<0.05)$. No significant relationships were found between the introduction of the innovation types isolated and productivity/avg industry. When we consider the systemic degree of innovation we have a similar pattern, as it is more positively associated with financial performance for the CNEUs. For this group, there is 
a positive relationship between the simultaneous introduction of more types of innovation and the three proxies of financial performance ( 0.06 with $p<0.05$ in total sales/avg industry, 0.07 with $p<0.01$ in num employees/avg industry and 0.09 with $\mathrm{p}<0.05$ in productivity/avg industry). In the case of the CEUs, the relationship is negative for total sales/ avg industry $(-0.02$ with $\mathrm{p}<0.01)$ and for productivity/avg industry $(-0.07$ with $\mathrm{p}<0.05)$. For num employees/avg industry, there is not a significant relationship.

Table 4 shows the results of the weighted logistic regressions that estimated each of the four innovation dummies (product, process, organizational and marketing) for both firm groups. Table 5 shows the regression that estimated systemic degree of innovation. Hypothesis 2 proposed that subsides from the government or from the EU have a stronger positive impact on the innovation performance of the CEUs' manufacturing SMEs, and that this relationship is positively moderated by the absorptive capacity of the firm. Table 4 and 5 showed that governmental support alone does not have a significant effect for any type of innovation or for systemic degree of innovation in any group. When we analyze the interaction between governmental support and the absorptive capacity proxies (internal $R \& D$, top management experience and employee education), we can perceive that the moderation of top management experience has a more consistent positive effect on the innovation outcomes for the CEUs' manufacturing SMEs. There is a significant positive effect for this group on product innovation $(0.06$ for $p<0.01)$, process innovation $(0.07$ for $p<0.01)$, organizational innovation $(0.04$ for $p<0.1)$ and systemic degree of innovation $(0.24$ for $p<0.01$ ). For the CNEUs', there is no significant effect of any moderation indicators. The moderation of the other two absorptive capacity proxies presented different results. In the case of internal R\&D, no significant moderation relationships with governmental support was found, contrasting with the direct positive relationship between this proxy and all innovation variables for both groups. For employee education, we could only observe a negative moderation for the CEUs' on systemic degree of innovation $(-0.10$ for $p<0.1)$ and no other significant relationships. All these results partially support hypothesis 2 . 
Table 2

Regression analysis of financial performance per group: separate innovation dummies

\begin{tabular}{|c|c|c|c|c|c|c|}
\hline \multirow[t]{2}{*}{ Independent Variables } & \multicolumn{2}{|c|}{$\begin{array}{l}\text { Total Sales/ } \\
\text { Avg Industry }\end{array}$} & \multicolumn{2}{|c|}{$\begin{array}{l}\text { Num Employees/ } \\
\text { Avg Industry }\end{array}$} & \multicolumn{2}{|c|}{$\begin{array}{l}\text { Productivity/ } \\
\text { Avg Industry }\end{array}$} \\
\hline & $\begin{array}{c}\text { CEUs } \\
\left(R^{2}=0.60 ;\right. \\
\left.\text { Adj } R^{2}=0.60\right) \\
\beta_{\text {Std. Error }}\end{array}$ & $\begin{array}{c}\text { CNEUs } \\
\left(R^{2}=0.68 ;\right. \\
\left.\text { Adj } R^{2}=0.67\right) \\
\beta_{\text {Std. Error }}\end{array}$ & $\begin{array}{c}\text { CEUs } \\
\left(R^{2}=0.87 ;\right. \\
\left.\text { Aju } R^{2}=0.86\right) \\
\beta_{\text {Std. Error }}\end{array}$ & $\begin{array}{c}\text { CNEUs } \\
\left(R^{2}=0.86 ;\right. \\
\left.\text { Aju } R^{2}=0.86\right) \\
\beta_{\text {Std. Error }}\end{array}$ & $\begin{array}{c}\text { CEUs } \\
\left(R^{2}=0.09 ;\right. \\
\left.\text { Aju } R^{2}=0.07\right) \\
\beta_{\text {Std. Error }}\end{array}$ & $\begin{array}{c}\text { CNEUs } \\
\left(R^{2}=0.25 ;\right. \\
\left.\text { Aju } R^{2}=0.24\right) \\
\beta_{\text {Std. Error }}\end{array}$ \\
\hline \multicolumn{7}{|l|}{ Innovation Performance } \\
\hline Product Innovation & $-0.01_{0.15}$ & $0.04_{0.12}$ & $-0.01_{0.04}$ & $0.06 *{ }_{0.05}$ & $-0.02_{0.19}$ & $0.01_{0.12}$ \\
\hline Process Innovation & $-0.01_{0.17}$ & $0.06 *_{0.12}$ & $0.01_{0.05}$ & $0.00_{0.06}$ & $-0.02_{0.21}$ & $0.06_{0.13}$ \\
\hline Organizational Innovation & $0.01_{0.18}$ & $-0.01_{0.14}$ & $0.03_{0.05}$ & $0.00_{0.06}$ & $-0.02_{0.22}$ & $0.06_{0.14}$ \\
\hline Marketing Innovation & $-0.01_{0.16}$ & $-0.02_{0.13}$ & $-0.02_{0.05}$ & $0.04_{0.06}$ & $-0.04_{0.21}$ & $-0.03_{0.13}$ \\
\hline \multicolumn{7}{|l|}{ Control Variables } \\
\hline Subsidiary & $0.08^{* * *} *_{0,28}$ & $0.00_{0,27}$ & $0.02_{0,08}$ & $-0.03_{0,12}$ & $0.06_{0,35}$ & $-0.02_{0,27}$ \\
\hline Firm's Age & $-0.04_{0,01}$ & $0.00_{0,00}$ & $-0.02_{0,00}$ & $-0.01_{0,00}$ & $-0.03_{0,01}$ & $0.00_{0,00}$ \\
\hline Export Intensity & $0.04_{0,00}$ & $-0.02_{0,00}$ & $0.04^{* *}{ }_{0,00}$ & $-0.03_{0,00}$ & $0.00_{0,00}$ & $0.06_{0,00}$ \\
\hline $\begin{array}{l}\text { Total Annual Sales } \\
\text { (year - 3) }\end{array}$ & $0.61^{* * * 00}$ & $0.66^{* * *}{ }_{0,00}$ & $0.05^{* * *}{ }_{0,00}$ & $0.11^{* * *}{ }_{0,00}$ & $0.33^{* * *} *_{0,00}$ & $0.54^{* * *}{ }_{0,00}$ \\
\hline $\begin{array}{l}\text { Num Employees } \\
\text { (year - 3) }\end{array}$ & $0.22^{* * * 00}$ & $0.29 * * *{ }_{0,00}$ & $0.89 * * * *_{0,00}$ & $0.88^{* * *} *_{0,00}$ & $-0.17^{* * *}{ }_{0,00}$ & $-0.21_{0,00}^{* * *}$ \\
\hline \multicolumn{7}{|l|}{ Ajuste de Modelo } \\
\hline F-test & $113.81 * * *$ & $104.45^{* * *}$ & $483.51 * * *$ & $301.59 * * *$ & $7.04 * * *$ & $16.82^{* * *}$ \\
\hline
\end{tabular}

$* \mathrm{p}<0.1 ; * * \mathrm{p}<0.05 ; * * * \mathrm{p}<0.01$

Source: Elaborated by the authors.

Table 3

Regression analysis of financial performance per group: Systemic Degree of Innovation

\begin{tabular}{|c|c|c|c|c|c|c|}
\hline \multirow[t]{2}{*}{ Independent Variables } & \multicolumn{2}{|c|}{ Product Innovation } & \multicolumn{2}{|c|}{ Process Innovation } & \multicolumn{2}{|c|}{ Organizational Innovation } \\
\hline & $\begin{array}{c}\text { CEUs } \\
\left(R^{2}=0.60 ;\right. \\
\left.\text { Aju } R^{2}=0.60\right) \\
\beta_{\text {Std. Error }}\end{array}$ & $\begin{array}{c}\text { CNEUs } \\
\left(R^{2}=0.67 ;\right. \\
\left.\text { Aju } R^{2}=0.67\right) \\
\beta_{\text {Std. Error }}\end{array}$ & $\begin{array}{c}\text { CEUs } \\
\left(R^{2}=0.87 ;\right. \\
\left.\text { Aju } R^{2}=0.86\right) \\
\beta_{\text {Std. Error }}\end{array}$ & $\begin{array}{c}\text { CNEUs } \\
\left(R^{2}=0.86 ;\right. \\
\left.\text { Aju } R^{2}=0.86\right) \\
\beta_{\text {Std. Error }}\end{array}$ & $\begin{array}{c}\text { CEUs } \\
\left(R^{2}=0.07 ;\right. \\
\left.\text { Aju } R^{2}=0.08\right) \\
\beta_{\text {Std. Error }}\end{array}$ & $\begin{array}{c}\text { CNEUs } \\
\left(R^{2}=0.25 ;\right. \\
\left.\text { Aju } R^{2}=0.24\right) \\
\beta_{\text {Std. Error }}\end{array}$ \\
\hline $\begin{array}{l}\text { Systemic Degree } \\
\text { Innovation }\end{array}$ & $-0.02 * * * *_{0,04}$ & $0.06^{* * 03}$ & $0.01_{0,01}$ & $0.07 * * * *_{0,01}$ & $-0.07 * *_{0,06}$ & $0.09 * *_{0,03}$ \\
\hline \multicolumn{7}{|l|}{ Control Variables } \\
\hline Subsidiary & $0.080 * * * *_{0,28}$ & $0.00_{0,27}$ & $0.02_{0,08}$ & $-0.03_{0,12}$ & $0.06_{0,35}$ & $-0.02_{0,27}$ \\
\hline Firm's Age & $-0.04_{0,01}$ & $0.03_{0,00}$ & $-0.02_{0,00}$ & $-0.01_{0,00}$ & $-0.03_{0,01}$ & $-0.01_{0,00}$ \\
\hline Export Intensity & $0.04_{0,00}$ & $-0.020_{0,00}$ & $0.04 *{ }_{0,00}$ & $-0.03_{0,00}$ & $0.00_{0,00}$ & $0.06_{0,00}$ \\
\hline $\begin{array}{l}\text { Total Annual Sales } \\
\text { (year - 3) }\end{array}$ & $0.61_{0,00}$ & $0.66^{* * *}{ }_{0,00}$ & $0.05^{* * *}{ }_{0,00}$ & $0.10 * * *{ }_{0,00}$ & $0.33^{* * *}{ }_{0,00}$ & $0.54 * * *{ }_{0,00}$ \\
\hline $\begin{array}{l}\text { Num Employees } \\
\text { (year-3) }\end{array}$ & $0.22_{0,00}^{* * *}$ & $0.28^{* * *}{ }_{0,00}$ & $0.88^{* * *}{ }_{0,00}$ & $0.88^{* * *}{ }_{0,00}$ & $-0.17 * * *{ }_{0,00}$ & $-0.21_{0,00}^{* * *}$ \\
\hline \multicolumn{7}{|l|}{ Model Fit Statistics } \\
\hline F-test & $171.31^{* * *}$ & $155.72 * * *$ & $724.38 * * *$ & $451.50 * * *$ & $10.59 * * *$ & $25.03^{* * *}$ \\
\hline
\end{tabular}

$* p<0.1 ; * *<<0.05 ; * * *<0.01$

Source: Elaborated by the authors. 
Table 4

Logit of the innovation performance dummies per group

\begin{tabular}{|c|c|c|c|c|c|c|c|c|}
\hline \multirow[t]{3}{*}{$\begin{array}{c}\text { Independent } \\
\text { Variables }\end{array}$} & \multicolumn{2}{|c|}{$\begin{array}{c}\text { Product } \\
\text { Innovation }\end{array}$} & \multicolumn{2}{|c|}{$\begin{array}{c}\text { Process } \\
\text { Innovation }\end{array}$} & \multicolumn{2}{|c|}{$\begin{array}{l}\text { Organizational } \\
\text { Innovation }\end{array}$} & \multicolumn{2}{|c|}{$\begin{array}{l}\text { Marketing } \\
\text { Innovation }\end{array}$} \\
\hline & CEUs & CNEUS & CEUs & CNEUs & CEUs & CNEUs & CEUs & CNEUs \\
\hline & $\beta_{\text {Std. Error }}$ & $\beta_{\text {Std. Error }}$ & $\beta_{\text {Std. Error }}$ & $\beta_{\text {Std. Error }}$ & $\beta_{\text {Std. Error }}$ & $\beta_{\text {Std. Error }}$ & $\beta_{\text {Std. Error }}$ & $\beta_{\text {std. Error }}$ \\
\hline \multicolumn{9}{|l|}{ Absorptive Capacity } \\
\hline Top & & & & & & & & \\
\hline $\begin{array}{l}\text { Management } \\
\text { Experience }\end{array}$ & $-0.02_{0,01}$ & $0.01_{0,01}$ & $-0.02_{0,01}$ & $0.00_{0,01}$ & $0.02_{0,01}$ & $-0.00_{0,01}$ & $0.00_{0,01}$ & $0.02_{0,01}$ \\
\hline Internal $R \& D$ & $2.24^{* * * 31}$ & $2.15^{* * * 36}$ & $1.23^{* * 2 *}$ & $2.03 * * * *_{0,33}$ & $1.31_{0,27}^{* *}$ & $2.94 * * * *_{0,38}$ & $0.80 * * *{ }_{0,27}$ & $2.20 * * *_{0,33}$ \\
\hline $\begin{array}{l}\text { Employee } \\
\text { Education }\end{array}$ & $0.63_{0,47}$ & $-0.42_{0,55}$ & $1.61_{0,47}^{* * *}$ & $-0.18_{0,57}$ & $0.71_{0,48}$ & $0.18_{0,61}$ & $1.32 * * * *_{0,47}$ & $-0.14_{0,61}$ \\
\hline $\begin{array}{l}\text { Governmental } \\
\text { support }\end{array}$ & $-0.41_{0,53}$ & $-0.61_{0,92}$ & $-0.78_{0,56}$ & $0.42_{0,88}$ & $0.04_{0,56}$ & $-0.03_{0,94}$ & $0.72_{0,54}$ & $-0.35_{1,00}$ \\
\hline \multicolumn{9}{|l|}{ Interactions } \\
\hline $\begin{array}{l}\text { Top } \\
\text { Management } \\
\text { Experience * } \\
\text { Governmental } \\
\text { support }\end{array}$ & $0.06^{* * *}{ }_{0,02}$ & $0.08_{0,05}$ & $0.07 * * *{ }_{0,02}$ & $0.01_{0,05}$ & $0.04{ }^{*}{ }_{0,02}$ & $0.02_{0,05}$ & $-0.02_{0,02}$ & $0.05_{0,06}$ \\
\hline $\begin{array}{l}\text { Internal R\&D * } \\
\text { Governmental } \\
\text { support }\end{array}$ & $-0.44_{0,55}$ & $0.36_{1,06}$ & $0.06_{0,49}$ & $0.72_{0,99}$ & $-0.37_{0,49}$ & $-0.88_{0,86}$ & $-0.33_{0,49}$ & $-0.79_{0,86}$ \\
\hline $\begin{array}{l}\text { Employee } \\
\text { Education * } \\
\text { Governmental } \\
\text { support }\end{array}$ & $-0.91_{1,11}$ & $-0.74_{2,07}$ & $-1.74_{1,06}$ & $-3.52_{2,70}$ & $-1.57_{1,09}$ & $-0.35_{2,09}$ & $-1.65_{1,05}$ & $-2.79_{2,68}$ \\
\hline \multicolumn{9}{|l|}{ Control Variables } \\
\hline Subsidiary & $0.35_{0,38}$ & $0.32_{0,64}$ & $0.05_{0,39}$ & $0.52_{0,64}$ & $0.52_{0,38}$ & $-0.24_{0,75}$ & $0.32_{0,38}$ & $-0.26_{0,74}$ \\
\hline Firm's Age & $-0.01^{*}{ }_{0,01}$ & $0.01_{0,01}$ & $-0.00_{0,01}$ & $0.01_{0,01}$ & $-0.02 *_{0,01}$ & $-0.01_{0,01}$ & $0.00_{0,01}$ & $0.01_{0,01}$ \\
\hline Export Intensity & $0.00_{0,00}$ & $0.00_{0,01}$ & $0.00_{0,00}$ & $0.00_{0,01}$ & $0.00_{0,00}$ & $-0.01_{0,01}$ & $-0.01 *{ }_{0,00}$ & $-0.01_{0,01}$ \\
\hline $\begin{array}{l}\text { Total Annual } \\
\text { Sales (year - 3) }\end{array}$ & $0.00_{0,00}$ & $0.00_{0,00}$ & $0.00_{0,00}$ & $0.00_{0,00}$ & $0.00_{0,00}$ & $0.00_{0,00}$ & $0.00_{0,00}$ & $0.00_{0,00}$ \\
\hline $\begin{array}{l}\text { Num Employees } \\
\text { (year - 3) }\end{array}$ & $0.00_{0,00}$ & $0.00_{0,00}$ & $0.00_{0,00}$ & $0.00_{0,00}$ & $0.00_{0,00}$ & $0.01 * *_{0,00}$ & $0.00_{0,00}$ & $0.01^{*}{ }_{0,00}$ \\
\hline Constant & $0.54_{0,39}$ & $0.06_{0,70}$ & $-0.83_{0,38}^{*}$ & $0.58_{0,71}$ & $-0.73_{0,39}$ & $-0.47_{0,67}$ & $-0.50_{0,38}$ & $-1.43^{* * 66}$ \\
\hline \multicolumn{9}{|l|}{ Model Fit } \\
\hline Correct Predict & $69.2 \%$ & $70.0 \%$ & $69.9 \%$ & $74.8 \%$ & $72.8 \%$ & $80.7 \%$ & $72.8 \%$ & $79.0 \%$ \\
\hline Chi-square test & $111.81 * * *$ & $76.67 * * *$ & $66.74 * * *$ & $66.27 * * *$ & $56.76 * * *$ & $104.70 * * *$ & $24.51 * *$ & $73.15^{* * *}$ \\
\hline
\end{tabular}

$* \mathrm{p}<0.1 ; * * \quad \mathrm{p}<0.05 ; * * * \mathrm{p}<0.01$

Source: Elaborated by the authors. 
Table 5

Regression analysis of Systemic Degree of Innovation per group

\begin{tabular}{|c|c|c|}
\hline \multirow[t]{2}{*}{ Independent Variables } & \multicolumn{2}{|c|}{ Systemic Degree of Innovation } \\
\hline & $\begin{array}{c}\text { CEUs } \\
\left(R^{2}=0.14 ;\right. \\
\left.\text { Adj } R^{2}=0.12\right) \\
\beta_{\text {std. Error }}\end{array}$ & $\begin{array}{c}\text { CNEUs } \\
\left(\mathrm{R}^{2}=0.28 ;\right. \\
\left.\text { Adj } \mathrm{R}^{2}=0.26\right) \\
\beta_{\text {std. Error }}\end{array}$ \\
\hline \multicolumn{3}{|l|}{ Absorptive Capacity } \\
\hline Top Management Experience & $-0.03_{0.00}$ & $0.031_{0.01}$ \\
\hline Internal $R \& D$ & $0.33 * * *_{0.12}$ & $0.52 * * *{ }_{0.13}$ \\
\hline Employee Education & $0.13 * * *{ }_{0.21}$ & $-0.02_{0.21}$ \\
\hline Governmental support & $-0.03_{0.23}$ & $-0.02_{0.33}$ \\
\hline \multicolumn{3}{|l|}{ Interactions } \\
\hline $\begin{array}{l}\text { Top Management Experience } \\
\text { * Governmental support }\end{array}$ & $0.24 * * *{ }_{0.01}$ & $0.09_{0.02}$ \\
\hline $\begin{array}{l}\text { Internal R\&D } \\
\text { * Governmental support }\end{array}$ & $-0.04_{0.22}$ & $-0.04_{0.32}$ \\
\hline $\begin{array}{l}\text { Employee Education } \\
\text { * Governmental support }\end{array}$ & $-0.1 *_{0.46}^{*}$ & $-0.05_{0.71}$ \\
\hline \multicolumn{3}{|l|}{ Control Variables } \\
\hline Subsidiary & $0.04_{0.17}$ & $0.01_{0.25}$ \\
\hline Firm's Age & $-0.06_{0.00}$ & $0.03_{0.00}$ \\
\hline Export Intensity & $-0.04_{0.00}$ & $-0.05_{0.00}$ \\
\hline Total Annual Sales (year - 3) & $0.00_{0.00}$ & $0.00_{0.00}$ \\
\hline Num Employees (year - 3) & $0.02_{0.00}$ & $0.07_{0.00}$ \\
\hline \multicolumn{3}{|l|}{ Model Fit Statistics } \\
\hline F-test & $8.89 * * *$ & $14.26 * * *$ \\
\hline
\end{tabular}

$* \mathrm{p}<0.1 ; * * \mathrm{p}<0.05 ; * * * \mathrm{p}<0.01$

Source: Elaborated by the authors.

\section{DISCUSSION}

The empirical analysis supported in most part hypothesis 1, indicating that innovation in general and especially systemic innovation have a positive impact on innovation performance of the CNEU's manufacturing SMEs in the short-term. These findings may be explained because countries of this group have weaker NSIs and their firms tend to be in a less developed stage regarding their innovation capabilities' accumulation process (BELL and FIGUEIREDO, 2012). Therefore, their effort to innovate in a systemic way may be felt faster than in more structured firms of more developed and global economies, such as the CEUs in comparison to the CNEUs. The fact that process innovation impacted in a positive way total sales /avg industry in the CNEUs' was probably found because, in these manufacturing SMEs, production and sales processes were less developed and a change on them contributed for catching-up a little more with the industry's patterns, which caused an immediate impact on its revenues. The positive effect of product innovation in num employees /avg industry found in the same group may also be explained by a similar argument. The fact that the CNEUs' manufacturing SMEs are less structured than the CEUs' and were not able to absorb the impacts of the introduction of product innovation obligated them to hire more people (sales team for example) to develop and commercialize the new products. The fact that the CEUs' firms are bigger than CNEUs' on average may corroborate this proposition. 
The stronger positive impact in CNEUs' manufacturing SMEs that introduced several types of innovation simultaneously reinforces the effectiveness of more systemic innovations, in which the introduction of new products and services that meets a new demand (product innovation) are followed by adaptations in the production process to guarantee an acceptable cost and quality (achieved by process innovations) and new ways to communicate the new products and services to new and old clients (by market innovations). These conjoint initiatives in many cases correspond to the introduction of new business models (CHESBROUGH, 2010), that also demand new organizational practices and methods (organizational innovation).

Although the hypothesis proposed that firms in less developed countries should feel the effects of innovation on financial performance faster, this effect should also sometime be found in more developed economies (such as the CEUs compared to the CNEUs). However, a time-lag between the introduction of innovation and an improvement in the financial performance might exist (PAULA and SILVA, 2018) and be more prominent in this case. In our empirical analysis, the financial performance is measured just in the end of the period in which the innovation introduction is measured without any time-lag (in the end of the three-year period in which the innovation introduction is considered). So, it is expected that the financial results of the innovation come with some delay and, although some innovations may have been introduced almost three years before the financial performance measure, some may have been introduced just before the measurement. The absence of impact of the introduction of individual types of innovation and the negative impact of systemic innovation in several indicators of financial performance of the CEUs' may be explained by the fact that it was too early to capture the effect of the innovation introduction on the financial indicators, as the sales of the new products were still not considered. Additionally, the effort made by the firms to develop the innovations took resources from sales efforts (ibid.).

Hypothesis 2 was also supported in most part. The more consistent positive effect of governmental support on product and process innovation in the CEUs' may come from the participation in EU's innovation development programs that focus more on quantifiable innovation, such as these two types. There is a weaker effect in organizational innovation that may derive by changes firms made in its organizational structure caused by the introduction of new products and processes (which consist in some degree in systemic innovations). Manufacturing SMEs in this group of countries uses governmental or EU support to make innovation more systemic and not only focused in one type. The CNEUs' manufacturing SMEs firms, on the other hand, which are in less developed countries, are less global, export less and innovate less, may not still have the necessary absorptive capacity to turn the support received by their governments into successful innovation introduction. Regarding the proxies of absorptive capacity, the experience of the top management is the most effective capability that allows the firm to turn the governmental support into innovation. This happens because experienced managers have more connections in the government and allow their firms to get more governmental incentives. They also have previous experience on choosing where to invest the money took from the government to innovate successfully. Internal R\&D itself improves innovation in the firms of both groups, although it does not affect the level of transformation of governmental incentives into innovation. That is a natural consequence of the efforts these firms do to innovate and improve their technological learning (KIM, 1997), that are represented by the intensity of investments in internal R\&D, and shows that these efforts are being directed correctly.

\section{CONCLUSION}

This paper empirically investigated the relevance of the relationship with the government in the development of the four types of innovation described by the Oslo Manual (product, process, organizational and marketing) in manufacturing SMEs of two different groups of CEE countries that changed from socialism to capitalism after the fall of the Berlin wall in 1989: the ones that joined the European Union (CEUs), and the ones that are out of EU (CNEUs). An analysis of a sample of 1,143 manufacturing SMEs, 684 from the CEUs and 459 from the CNEUs, from the BEEPs survey of 2011 and 2012, lead us to interesting conclusions. The higher average of the CEUs' in the three performance indicators analyzed in this manuscript is consistent with our proposition that a higher performance of firms in a country helps to improve its economic development, which is also higher for CEUs. This fact comes with higher governmental support; higher export intensity, which may be also caused by the participation in the EU's free market; and higher introduction of innovation in general, although it we could not observe differences in the introduction of each type of innovation separately. 
The first analysis made by this paper was concerning the effect of the different types of innovation introduced and how broad this introduction was (introduction of diverse types of innovation in the period, which was called systemic degree of innovation) on immediate financial performance proxies. We could only analyze the effects of innovation introduction in the immediate financial performance as we did not have access to lagged data. The main stream literature frequently demonstrates that the effect of innovation on firm performance presupposes the existence of a time-lag between them and that a short-term effect would not be observed. This was true in the case of the CEUs' manufacturing SMEs when we analyzed the effect of the introduction of the four different types of innovation separately on the immediate financial performance. The effect was negative in the case of systemic degree of innovation, maybe caused by redirection of resources from direct marketing and sales to innovative activities, such as internal R\&D, that may have provoked an immediate decrease of sales. However, the findings were different in the case of firms from the CNEUs, which are less developed compared to the CEUs. The impacts of innovation introduction on immediate firm performance was observed on firm size (product innovation on num. employees/avg. industry) and on sales (process innovation on total sales/avg. industry). It possibly happened because CNEUs' manufacturing SMEs are not well structured to innovate and should hire employees to execute product innovation activities, justifying an increase in the number of employees. At the same time, innovative changes in their processes may have helped them to catch-up to international industry patterns that improved their immediate sales and, in consequence, revenues. In the case of systemic degree of innovation, a positive effect on immediate performance was strongly felt in the CNEUs'. This may have been caused because the manufacturing SMEs from the CNEUs are more distant from the technological frontier than firms from the CEUs, but the ones that innovate in a more systemic way are closer. So, the high inequality in the innovative and technological levels of the firms inside the group causes this positive effect. Therefore, one of the main contributions of this study was finding that, on the contrary of what was found in most previous studies, innovation is effective to promote an increase in firm performance in the short-term in less developed countries. The diagnosis that we can make here is that firms in the CNEUs should invest in developing innovative capabilities in a systemic way to catch-up with the most developed firms in their group and with firms from more developed countries. This may help them to improve their performance even without the free access to the EU market. This type of investment may also help less developed firms in the CEUs to catch-up. In short, the less developed is the country in which the firm is based, the faster is the effect of innovation on the financial performance because these firms are so outdated compared to their competitors of more developed economies that any innovative effort may quickly be felt. This effect is stronger if the firms develop innovation in a more systemic way, which usually demonstrates a more advanced firm-level stage of technological development. These findings may contribute to demonstrate to shareholders of firms from developing economies that investing in innovation capabilities is not only a long-term investment, but can also improve their shares' return in the short-term.

The second analysis concerned the effect of the government and EU official programs in facilitating innovation development. No direct relationship could be found for any of the groups between governmental support and innovation. When we considered the moderation effect of the absorptive capacity on the governmental support, specifically in the case of the proxy top management experience, its effect was positive only for CEUs' manufacturing SMEs in several dimensions of innovation. This corroborates with the absorptive capacity theory, since the partnership with the government (which was considered as a partner in a strategic alliance) only results in successful innovation if the firm has a high capacity to identify, absorb and apply the knowledge and resources from its partners. These results also indicated three points: first, the relationship among the top management and the government is important to posit the organization well to get advantage of the government's innovation incentives and use them in an effective way. Second, the EU official bodies and programs to improve innovation, that are accessed by EU participants, are more effective in boosting innovation than country-specific policies. This higher effectiveness of the EU policies may have emerged by the integration between countries from the group, that increased the market for new products and partnerships with more innovative firms of developed countries. Third, there is gap between the absorptive capacity of firms from the CEUs and the ones from the CNEUs, that can be reduced only by investments in knowledge, technology and innovation capabilities. A suggestion for the CNEUs' governments is to make an agreement to join forces and launch supra-national innovation policies and programs to benefit their firms. It could improve the effectiveness of these policies and increase their funding capacity. But it is important that these programs and policies require the benefited 
Eastern Europe manufacturing SMEs

firms to develop their own technology and innovation capabilities in order to be capable to compete in the whole Europe and in other international markets.

We may point several limitations in this study. The first limitation is that the effects of innovation on financial performance may take some time to be noticed by all firms but the data did not provide financial results with a higher time-lag. The weak relationships between some of the innovation performance indicators and some of the financial performance indicators may be an effect of the absence of this time-lag. Another limitation is caused by the usage of a pre-existent survey like BEEPs. It limits the flexibility of variables that can be studied. In this paper's case, some proxies that would be more appropriate to be represented by scalar variables are actually dummy variables in BEEPs, such as the absorptive capacity proxy Internal $R \& D$, that would be better represented by total expenses in R\&D / total annual sales. Similar questionings can be made for the innovation performance dummy variables (product, process, organizational and marketing innovation). These are also dummies but could be measured differently, for instance as the amount of each type of innovation introduced in the period. On the other hand, the measurement of scalar variables or of the amount of innovations could be less reliable than dummy variables. Anyway, the construction of an instrument made specifically to fit the research purposes is an opportunity for future studies. Finally, BEEPs survey is based on answers of respondents subject to momentaneos fellings and experiences, besides other factor that may bias the survey's results.

Despite these limitations, this paper presented a valuable contribution for firms' managers and policy makers to better understand the relationships among the governmental support and the four types of innovation introduction, and the effect of innovation on firm performance in ex-socialist European countries. It is clear that the participation in the EU was important to improve the countries' firms performance. However, innovation may help firms from the countries out of EU to catch-up with the ones from EU countries. The solution for these firms is to invest more simultaneously in innovation of diverse types, which can boost their tecnological capabilities and improve their immediate financial performance. Their countries' governments should join forces to launch joint supra-national innovation policies and programs to increase their capacity to support their firms in developing systemic innovation. Additionally, firms should make an effort to hire experienced managers, with links to the government, to take more advantage of the innovation support programs. As a suggestion for future studies, we can propose expanding this study for other developing and developed countries to check if the differences found here are confirmed. Another suggestion is to replicate this study in firms from other sectors, such as service firms. 


\section{REFERENCES}

APANASOVICH, N.; HERAS, H. A.; PARRILLI, M. D. The impact of business innovation modes on SME innovation performance in postSoviet transition economies: the case of Belarus. Technovation, v. 57-58, p. 30-40, 2016.

ASLUND, A. Transition in perspective: 25 years after the fall of communism. 2017. Available at: <https://piie.com/blogs/realtimeeconomic-issues-watch/transition-perspective-25-years-after-fallcommunism?p=4312>. Accessed on: Jan. 15, 2017.

ATELJEVIĆ, J.; TRIVIĆ, J. (Eds.). Economic development and entrepreneurship in transition economies: issues, obstacles and perspectives. Basingstoke: Springer, 2016.

BELL, M.; FIGUEIREDO, P. N. Innovation capability building and learning mechanisms in latecomer firms: recent empirical contributions and implications for research. Canadian Journal of Development Studies/Revue canadienne d'études du développement, v. 33, n. 1, p. 14-40, 2012.

CAMISÓN, C.; VILLAR-LÓPEZ, A. Organizational innovation as an enabler of technological innovation capabilities and firm performance. Journal of Business Research, v. 67, n. 1, p. 2891-2902, 2014.

CASSIMAN, B.; GOLOVKO, E. Innovation and internationalization through exports. Journal of International Business Studies, v. 42, n. 1, p. 56-75, 2011.

CHESBROUGH, H. Business model innovation: opportunities and barriers. Long Range Planning, v. 43, n. 2/3, p. 354-363, 2010.

CHOUNG, J. Y.; HWANG, H. R.; SONG, W. Transitions of Innovation Activities in Latecomer Countries: An Exploratory Case Study of South Korea. World Development, v. 54, p. 156-167, 2014.

CHRISTENSEN, C.; RAYNOR, M. The innovator's solution: creating and sustaining successful growth. Cambridge: Harvard Business Review Press, 2013.

COHEN, W. M.; LEVINTHAL, D. Absorptive Capacity : A New Perspective on Learning and Innovation. Administrative Science Quarterly, v. 35, n. 1, p. 128-152, 1990.

DUTTA, S.; LANVIN, B.; WUNSCH-VINCENT, S. (Eds.). The Global Innovation Index 2016: winning with global innovation. Cornell University, INSEAD, the World Intellectual Property Organization (WIPO): Ithaca, Fontainebleau, Geneva, 2016.

DU, J.; LETEN, B.; VANHAVERBEKE, W. Managing open innovation projects with science-based and market-based partners. Research Policy, v. 43, n. 5, p. 828-840, 2014.

EUROPEAN BANK FOR RECONSTRUCTION AND DEVELOPMENT EBRD. Business Environment and Enterprise Performance Survey (BEEPS). 2016. Available at: <http://ebrd-beeps.com/>. Accessed on: Oct. 25, 2016.

EUROPEAN COMMISSION - EC. European neighborhood policy and enlargement negotiations. 2017a. Available at: <https://ec.europa. eu/neighbourhood-enlargement/policy/conditions-membership/ chapters-of-the-acquis_en>. Accessed on: Feb. 02, 2017.

EUROPEAN COMMISSION - EC. What is an SME? 2017b. Available at: <http://ec.europa.eu/growth/smes/business-friendly-environment/ sme-definition_en>. Accessed on: Feb. 17, 2017.
EUROPEAN COMMISSION - EC. Funding for Innovation. 2017c. Available at: <https://ec.europa.eu/growth/industry/innovation/ funding_en>. Accessed on: Mar. 27, 2017.

EUROPEAN COMMISSION - EC. Innovation Policies. 2018. Available at: <https://ec.europa.eu/growth/industry/innovation/policy_en>. Accessed on: Mar. 27, 2017.

FEIGE, E. L. The transition to a market economy in Russia: property rights, mass privatization and stabilization. A fourth way, p. 57-78, 1994.

GALINDO, M. Á.; MÉNDEZ, M. T. Entrepreneurship, economic growth, and innovation: are feedback effects at work? Journal of Business Research, v. 67, n. 5, p. 825-829, 2014.

GHAZALIAN, P. L.; FAKIH, A. R\&D and innovation in food processing firms in transition countries. Journal of Agricultural Economics, v. 68, n. 2, p. 427-450, 2017.

GRIFFITH, R. et al. Innovation and productivity across four European countries. Oxford Review of Economic Policy, v. 22, n. 4, p. 483498, 2006.

GUPTA, S. et al. Marketing innovation: a consequence of competitiveness. Journal of Business Research, v. 69, n. 12, p. 5671-5681, 2016.

HAMEL, G. Management innovation. Leadership Excellence, v. 26, n. 5, 2009.

HAMEL, G.; VALIKANGAS, L. The quest for resilience. Harvard Business Review, v. 81, n. 9, p. 52-65, 2003.

HILL, C.; ROTHAERMEL, F. The performance of incumbent firms in the face of radical technological innovation. Academy of Management Review, v. 28, n. 2, p. 257-274, 2003.

HONG, J.et al. Do government grants promote innovation efficiency in China's high-tech industries? Technovation, v. 57, p. 4-13, 2016.

KIM, L. Imitation to innovation: the dynamics of Korea's technological learning. Cambridge: Harvard Business Press, 1997.

KIM, L. Crisis Construction and organizational learning: capability building in catching-up at Hyundai Motor. Organization Science, v. 9, n. 4, p. 506-521, 1998.

LAFORET, S. Organizational innovation outcomes in SMEs: effects of age, size, and sector. Journal of World Business, v. 48, n. 4, p. 490-502, 2013.

LEE, K.; LIM, C. Technological regimes, catching-up and leapfrogging: findings from the Korean industries. Research Policy, v. 30, n. 3, p. 459-483, 2001.

$\mathrm{MARCH}, \mathrm{J}$. Exploration and exploitation in organizational learning. Organization Science, v. 2, n. 1, p. 71-87, 1991.

MOUTINHO, R.; AU-YONG-OLIVEIRA, M.; COELHO, A.; MANSO, J. P. The role of regional innovation systems (RIS) in translating $R \& D$ investments into economic and employment growth. Journal of Technology Management \& Innovation, v. 10, n. 2, p. 9-23, 2015.

NELSON, R. R.; MOWERY, D. C.; FAGERBERG, J. The Oxford handbook of innovation. Oxford: Oxford University Press, 2005. 
The impact of different types of innovation and governmental

ORGANISATION FOR ECONOMIC COOPORATION AND DEVELOPMENT - OECD. Oslo manual: guidelines for collecting and interpreting innovation data. Paris: OECD, 2005.

PATEL, P.; PAVITT, K. The nature and economic importance of national innovation systems. STI review, v. 14, n. 1, p. 9-32, 1994.

PAULA, F. D. O.; SILVA, J. F. D. Balancing Internal and External R\&D Strategies to Improve Innovation and Financial Performance. BAR-Brazilian Administration Review, v. 15, n. 2, 2018.

PODSAKOFF, P. M.et al. Common method biases in behavioral research: a critical review of the literature and recommended remedies. Journal of Applied Psychology, v. 88, n. 5, p. 879-903, 2003.

PROPRIS, L. Types of innovation and inter-firm co-operation. Entrepreneurship \& Regional Development, v. 14, n. 4, p. $337-$ 353, 2002.

RADOSEVIC, S. Innovation policies in central and eastern European countries: are they meeting the challenges of knowledge-based growth in enlarged EU? In: JASINSKI, A. (Ed.). Transition economies in the European research and innovation area: new challenges for their science and technology. Warsaw: University of Warsaw, 2004. p. 95-114.

SCHOENMAKERS, W.; DUYSTERS, G. The technological origins of radical inventions. Research Policy, v. 39, n. 8, p. 1051-1059, 2010.

TEECE, D. Profiting from technological innovation: Implications for integration, collaboration, licensing and public policy. Research Policy, v. 15, n. 6, p. 285-305, 1986.

TEECE, D. Explicating dynamic capabilities: The nature and microfoundations of (sustainable) enterprise performance. Strategic Management Journal, v. 28, n. 3, p. 1319-1350, 2007.
TERJESEN, S.; PATEL, P. C. In search of process innovations: The role of search depth, search breadth, and the industry environment. Journal of Management, v. 43, n. 5, p. 1421-1446, 2017.

TOMLINSON, P. Co-operative ties and innovation: some new evidence for UK manufacturing. Research Policy, v. 39, n. 6, p. 762-775, 2010.

UNITED NATIONS - UN. Human Development Report 2015. 2015. Available at: <http://hdr.undp.org/sites/default/files/hdr_2015_ statistical_annex.pdf>. Accessed on: Jan. 22, 2017.

UTTERBACK, J. M.; ABERNATHY, W. J. 1975. A dynamic model of process and product innovation. Omega, v. 3, n. 6, p. 639-656, 1975.

VEGA-JURADO, J. et al. Integrating Technology, Management and Marketing Innovation through Open Innovation Models, Journal of Technology Management \& Innovation v. 10, n. 4, p. 85-90, 2015.

YAMAKAWA, Y.; YANG, H.; LIN, J. Exploration versus exploitation in alliance portfolio: Performance implications of organizational, strategic, and environmental fit. Research Policy, v. 40, n. 2, p. 287-296, 2011.

ZAHRA, S. A.; GEORGE, G. Absorptive capacity: A review, reconceptualization, and extension. Academy of Management Review, v. 27, n. 2, p. 185-203, 2002.

ZENG, S. X.; XIE, X. M.; TAM, C. M. Relationship between cooperation networks and innovation performance of SMEs. Technovation, v. 30, n. 3, p. 181-194, 2010.

Fábio de Oliveira Paula

ORCID: https://orcid.org/0000-0002-1926-2241

PhD in Business Administration by the Pontifical Catholic University of Rio de Janeiro (PUC-Rio); Assistant Professor at IAG Business School- Pontifical Catholic University of Rio de Janeiro, Rio de Janeiro - RJ, Brazil. E-mail: fabioop@iag.puc-rio.br

Jorge Ferreira da Silva

ORCID: https://orcid.org/0000-0002-0021-8398

PhD in Industrial Engineering by the Pontifical Catholic University of Rio de Janeiro (PUC-Rio); Full Professor at IAG Business School- Pontifical Catholic University of Rio de Janeiro, Rio de Janeiro - RJ, Brazil. E-mail: shopshop@iag.puc-rio.br 